\title{
Evaluating the Effectiveness of Best Management Practices in Gilgel Gibe Basin Watershed-Ethiopia
}

\author{
Tamene Adugna Demissie ${ }^{1}$, Fokke Saathoff ${ }^{2}$, Yilma Seleshi ${ }^{3}$ and Alemayehu Gebissa ${ }^{2}$ \\ 1. Department of Civil Engineering, Jimma Institute of Tehnology, Jimma University, Jimma 378, Ethiopia \\ 2. Institute for Environmental Engineering, University of Rostock, Rostock 18051, Germany \\ 3. Civil Engineering Department, Addis Ababa Institute of Technology, Addis Ababa University, Addis Ababa 150461, Ethiopia
}

\begin{abstract}
Soil erosion/sedimentation is an immense problem threatening the live storage capacity of dam reservoirs in Ethiopia. This in turn reduces the power generation capacities of hydropower reservoirs. Therefore, studies which give insight into soil erosion/sedimentation mechanisms and mitigation methods is important. The high rate of soil erosion/sedimentation threats the lifespan of Gilgel Gibe-1 hydropower reservoir. The problem of sedimentation in Gilgel Gibe-1 will also affect Gilgel Gibe- 2 which uses the water released from Gilgel Gibe-1. The sustainability of these hydropower plants needs catchment management practices that will reduce soil erosion. This paper presents the results of monthly and yearly sediment yield simulations experiments conducted for Gilgel Gibe-1 under different BMP (best management practice) scenarios. The scenarios applied in this paper are: (1) maintaining existing conditions; (2) introducing filter strips; (3) applying stone/soil bunds; (4) reforestation. The SWAT (soil and water assessment tool) was used to model soil erosion, identify soil erosion prone areas and assess the impact of BMPs on sediment reduction via simulations. The simulation results showed that applying filter strips, stone bunds and reforestation scenarios could reduce the current sediment yields at soil erosion prone areas and at the outlet of the catchment area which is the inlet to Gilgel Gibe-1 reservoir.
\end{abstract}

Key words: BMPs, SWAT, sedimentation.

\section{Introduction}

The Gilgel Gibe River is a right hand tributary of one of the eight major river basins in Ethiopia, the Omo-Gibe river basin. It is the major source of water for Gilgel Gibe dam reservoir project which has a live storage capacity of $657 \mathrm{Mm}^{3}$. But the storage volume of this reservoir is threatened by the soil erosion and subsequent sedimentation from the upstream of the Gilgel Gibe basin. Previous studies indicate that there is a rapid loss of storage volume due to excessive soil erosion and subsequent sedimentation in Gilgel Gibe-1 dam reservoir. Devi et al. [1] conducted a cross sectional study and assessed the siltation and nutrient enrichment level of Gilgel Gibe-1 dam reservoir. From their study, they found that siltation

Corresponding author: Tamene Adugna Demissie, M.Sc., research fields: water resources management and watershed modeling. E-mail: tamene_adu2002@yahoo.com. and nutrient enrichment were the major problems in this reservoir.

In addition to Gilgel Gibe-1 hydropower plant, the power generation of the Cascade hydropower plant to Gilgel Gibe-1, namely Gilgel Gibe-2 Which has an installed capacity of $420 \mathrm{MW}$ and uses the water released from the same reservoir, will significantly be affected.

Currently, the government of Ethiopia is constructing a huge hydropower plant, Gilgel Gibe-3, downstream of Gilgel Gibe-1 and 2. The Gilgel Gibe-3 dam and powerhouse are being built approximately $155 \mathrm{~km}$ downstream of the Gilgel Gibe-2 plant. Up on its completion Gilgel Gibe-3 will have an installed capacity of 1,870 MW. There is also a plan to construct Gilgel Gibe-4 which will be the farthest downstream in the cascade. Though the Government of Ethiopia is putting an effort to 
construct large hydropower plants to supply the energy demand of the country, the rapid loss of storage volume due to sedimentation is major problem of all reservoirs. Some preliminary studies indicate that the levels of some reservoirs (e.g., Koka reservoir), lakes (e.g., Alemaya, Awassa, Abaya and Langano) have decreased. The process is so challenging that the initial water carrying capacity the dams has reduced due to progressive silt accumulation. For example, the Koka dam has accumulated about 3.5 million $\mathrm{m}^{3}$ of silt (or $2,300 \mathrm{t} \cdot \mathrm{km}^{-2}$ ) in just 23 years [2]. Thus, an insight into the soil erosion/sedimentation mechanisms and the mitigation measures plays an indispensable role for the sustainability of the existing reservoirs and newly planned projects. To develop effective soil erosion control mechanisms through watershed development programs and to achieve reductions in sedimentation, it is necessary to quantify the sediment yield and identify areas that are highly vulnerable to erosion. Literature review shows that there are many catchment models that include the soil erosion/sedimentation processes and simulate the effect of mitigation measures $[3,4]$. The range of models can be viewed in the way they represent the area to which they are applied, that is, whether the model considers processes and parameters to be lumped or distribute. With increasing computing power over the last two decades, distributed approaches have become more feasible. Distributed models reflect the spatial variability of processes and outputs in the catchment analysis. A distributed approach seems particularly applicable to sediment transport modelling [4]. Some of the soil erosion models are AGNPS (agricultural non-point source pollution model) [5], ANSWERS (areal nonpoint source watershed environmental response simulation) [6], CREAMS (chemicals, runoff and erosion from agricultural management systems) [7], EPIC (erosion productivity impact calculator) [8], EROSION-3D [9], EUROSEM (European soil erosion model) [10],
SWAT (soil and water assessment tool) [11], WEPP (water erosion prediction project) [12], and so on. However, there are a few applications of erosion modelling in Ethiopia and most of them concentrate on Blue Nile basin. In the Blue Nile Basin [13] simulated soil loss in the Dembecha catchment using WEPP, Haregeweyn and Yohannes [14] applied AGNPS and predicted sediment yield in Augucho catchment. The same AGNPS model was used by Ref. [15] to simulate sediment yield in the kori catchment. Hengsdijk et al. [16] applied LISEM (limburg soil erosion model) to simulate effect of reforestation on soil erosion in the Kushet-Gobo Deguat catchment. Steenhuis et al. [17] calibrated and validated a simple soil erosion model in the Abbay (Upper Blue Nile) basin and obtained a reasonable result, and Setegn et al. [18] applied SWAT for simulation of a sediment yield in the Anjeni gauged catchment and obtained quite acceptable result. SWAT has been successfully applied by different researchers in Ethiopia. Most of the SWAT model applications in Ethiopia concentrate on the Blue Nile river basin. For instance, Tesfahunegn et al. [19] applied SWAT model to evaluate the effectiveness of different scenarios in reducing runoff, sediment and soil nutrient losses in northern Ethiopia. Asres and Awulachew [20] applied the SWAT model to establish the spatial distribution of sediment yield and to test the potential of watershed management measures to reduce sediment loading from hot spot areas in Gumara watershed (Blue Nile) and Betrie et al. [21] also applied the SWAT model to assess the impact of BMPs on sediment reductions in the Upper Blue Nile River Basin. Though the SWAT model is widely applied in Ethiopia, particularly on the Blue Nile river basin, there is no literature that indicates the SWAT model application on Omo-Gibe basin in general and Gilgel Gibe-1 basin in particular. In this study, the SWAT model has been applied to the Gilgel Gibe river basin with specific focus on BMPs application. Currently, there is a recommendation to protect the buffer zone around Gilgel Gibe-1 dam 
reservoir from agricultural practices. In addition to the buffer zone protection, the Oromiya Environmental Protection Bureau is also implementing watershed development through the community based participatory approach of Ref. [22] management practices to reduce soil erosion and conserve soil and water under its basin development programme. Such basin development programme should be aided by powerful modelling tools such as SWAT. Therefore, the objective of this study is to model the spatially distributed soil erosion/sedimentation process in the Gilgel Gibe basin at monthly and yearly time steps and assess the impact of different catchment management interventions applied on hot spot areas on sediment yield. A brief description of the Gilgel Gibe basin is given in the next section, followed by a discussion on the methodology used. The third section presents the model results and discussion of different land management scenarios. Finally, the conclusion summarizes the main findings of the investigations.

\section{Description of the Study Area}

As it is indicated in Fig. 1, the Gilgel Gibe-1 watershed is situated in the south-western part of Ethiopia. The project is purely a hydropower scheme, with an installed capacity of $180 \mathrm{Mw}$, aimed to increase energy and power supply to the national grid. The reservoir has a live storage capacity of $657 \mathrm{~mm}^{3}$. The catchment area of the Gilgel Gibe basin is about $5,125 \mathrm{~km}^{2}$ at its confluence with the great Gibe River and about $4,225 \mathrm{~km}^{2}$ at the dam site. The basin is generally characterized by high relief hills and mountains with an average elevation of about $1,700 \mathrm{~m}$ above mean sea level. The basin is largely comprises of cultivated land. In general terms, the Gilgel Gibe basin is characterized by wet climate with an average annual rainfall of about $1,550 \mathrm{~mm}$ and average temperature of $19{ }^{\circ} \mathrm{C}$. The seasonal rainfall distribution takes a uni-modal pattern with maximum during summer and minimum during winter, influenced by the ITCZ (inter-tropical convergence zone).

\section{Methodology}

\subsection{SWAT Model Description}

The SWAT is a physical process based model to

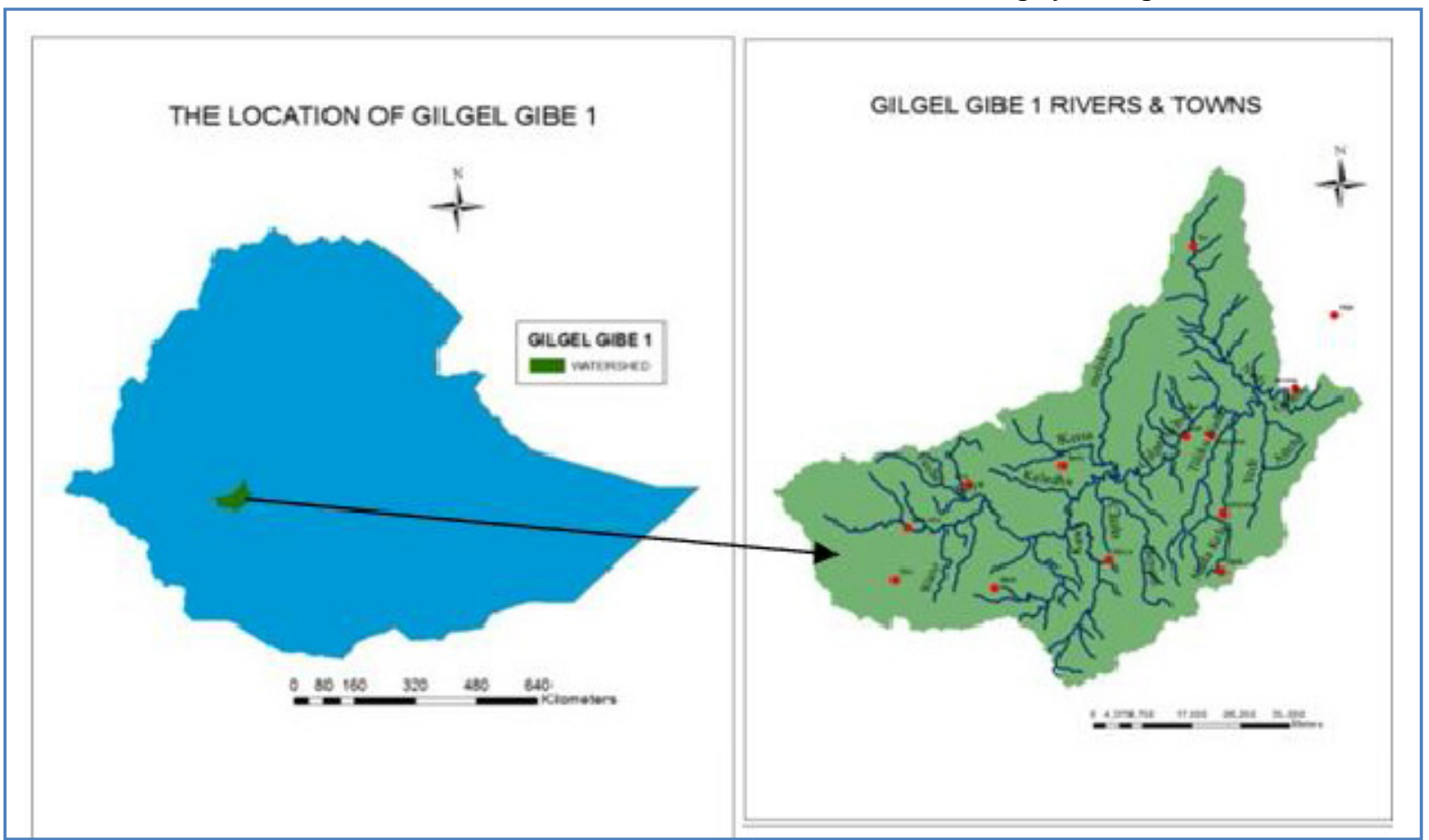

Fig. 1 Location map of the Gilgel Gibe-1 watershed. 
simulate continuous time landscape processes at a catchment scale $[11,21,23]$. The catchment is divided into HRU (hydrological response units) based on soil type, land use and slope classes. The major model components include hydrology, weather, soil erosion, nutrients, soil temperature, crop growth, pesticides agricultural management and stream routing. The model predicts the hydrology at each HRU using the water balance equation, which includes daily precipitation, runoff, evapo-transpiration, and percolation and return flow components. The SWAT model has two options for computing surface runoff: (1) the Natural Resources Conservation Service CN (Curve Number) method [24]; or (2) the Green-Ampt method [25]. The flow routing in the river channels is computed using the variable storage coefficient method [26], or Muskingum method [27]. SWAT includes three methods for estimating potential evapo-transpiration: (1) Priestley-Taylor [28]; (2) Penman-Monteith [29]; (3) Hargreaves [30]. The SWAT model employs the MUSLE (modified universal equations) to compute HRUs level soil erosion. It uses runoff energy to detach and transport sediment [31]. The sediment routing in the channel [32] consists of channel degradation using stream power [33] and deposition in channel using fall velocity. Channel degradation adjusted using USLE soil erodibility and channel cover factors.

\subsection{SWAT Model Setup}

SWAT model inputs are DEM (digital elevation model), land use map, soil map and weather data. There is a considerable amount of data available on the web, and Map Window SWAT used in this study used this advantage. MWSWAT (Map Window SWAT) is delivered along with the following data [34]: DEM maps: SRTM project [35]; Land: Global Land Cover characterization [36]; Soil maps: FAO (Food and Agricultural Organization) [37]. The Step by Step Geo-Processing \& Set up of the Map window interface for SWAT (MWSWAT) documents [38, 39], have been followed to extract the required watershed data and to set up the SWAT model for Gilgel Gibe basin. The DEM was used to delineate the catchment and provide topographic parameters such as overland slope and slope length for each sub-basin. The catchment area of the Gilgel Gibe was delineated and discretized into 51 sub-basins using a 90 m DEM [40] through an MWSWAT interface. The Land use data which has been constructed from the USGS Global Land Cover Characterization (GLCC) database [41], by Abbaspour is used. This map has a spatial resolution of $1 \mathrm{~km}$ and 24 classes of land use representation. The parameterization of the land use classes (e.g., leaf area index, maximum stomatal conductance, and maximum root depth, optimal and minimum temperature for plant growth) is based on the available SWAT land use classes. The land cover classes derived are CRDY (dry land Cropland and pasture), 36.68\%, Gras (Grassland), 15.56\%, SAVA (Savanna) 14.45\%, FOEB (evergreen forest) $22.65 \%$, FOMI (mixed forest) $9.92 \%$ and CRWO (Cropland/woodland mosaic), $0.74 \%$. The soil map was produced by the Food and Agriculture Organization of the United Nations [42]. Almost 5,000 soil types at a spatial resolution of $10 \mathrm{~km}$ with soil properties for two layers (0-30) $\mathrm{cm}$ and 30-100 $\mathrm{cm}$ depth) are provided. Further soil properties (e.g., particle-size distribution, bulk density, organic carbon content, available water capacity, and saturated hydraulic conductivity) were obtained from Ref. [43]. The soil data is also available from the Water Base web site [44], and was extracted for the study area. FAO soil and the slope class maps were overlaid together to derive 410 unique HRUs. Although the SWAT model provides an option to reduce the number of HRUs in order to enhance the computation time required for the simulation, we considered all of the HRUs with land use of dry land, cropland and pasture of to evaluate the management intervention impact. The daily precipitation, maximum and minimum temperature, wind speed, average relative 
humidity data from Jimma and Sekoru stations were used to run the model. In addition, as Jimma and Sekoru meteorological stations have daily data on duration of sunshine hours, the Angstrom formula which relates solar radiation to extraterrestrial radiation and relative sunshine duration is used to estimate the daily solar radiation to be used in the model. The missed sunshine data were filled by non-linear regression analysis with other auxiliary climate variables such as relative humidity and temperature data before it was used to estimate solar radiation. The solar radiation data is required by SWAT and if not supplied SWAT generates this data. Though all the daily weather data which are required to run the model have been supplied, the weather generator file was also prepared using the 20 years daily data from these two stations and included in the project file. Daily river flow data measured at Asendabo gauging station was used for model calibration and validation. The flow observations were available throughout the year, but the sediment concentration data was not available for Gilgel Gibe basin. The model was run using daily data of 26 years. The daily meteorological data from 1980 to 2005 was used to run the model. The three years data from 1980 to 1982 was used to warm up the model. Whereas, the data from 1983 to 1992 was used to calibrate the model and the data from 1993 to 2000 was used to validate the model. The modeling period selection considered discharge data quality and availability. A daily flow was used to calibrate and validate the model at Asendabo gauging station and sediment discharge was simulated at the outlet of the Gilgel Gibe watershed which is in turn an inlet to the Gilgel Gibe-1 hydropower reservoir. Sensitivity analysis was carried out to identify the most sensitive parameters for model calibration using LH-OAT (One-factor-At-a-Time), an automatic sensitivity analysis tool implemented in SWAT 2005. SWAT 2005 editor is used to read the project database generated by Map Window SWAT interface to edit
SWAT input files, execute SWAT, and perform sensitivity, auto calibration and uncertainty analysis. Based on the sensitivity analysis results, we identified 8 parameters of interest for this basin. We started with all 27 hydrological flow related parameters and ranked by their order of sensitivity in simulating the basin hydrology. It resulted in about 8 parameters as the most sensitive ones for this basin. Followed by the sensitivity analysis, the most sensitive parameters were calibrated by both manual calibration (expert) and automatic calibration. Appropriate lower and upper ranges in parameter values have been assigned prior to initiating the auto calibration process.

\subsection{Model Performance Evaluation}

Model evaluation is an essential measure to verify the robustness of the model. In this study, the following methods were used: (1) NSE (Nash-Sutcliffe efficiency); (2) PBIAS (percent bias); (3) correlation between observed and simulated flows. The NSE (Nash-Sutcliffe efficiency) is computed as the ratio of residual variance to measured data variances [45]. The NSE simulation coefficient indicates how well the plot of observed versus simulated values fits the 1:1 line. The Nash-Sutcliffe is calculated using Eq. (1):

$$
N S E=1-\left[\frac{\sum_{i=1}^{n}\left(Q_{i}^{o b s}-Q_{i}^{s i m}\right)^{2}}{\sum_{i=1}^{n}\left(Q_{i}^{o b s}-Q^{\text {mean }}\right)^{2}}\right]
$$

where,

$$
\begin{aligned}
& Q_{i}^{\text {obs }}=\text { observed stream flow in } \mathrm{m}^{3} / \mathrm{s} ; \\
& Q_{i}^{\text {sim }}=\text { simulated stream flow in } \mathrm{m}^{3} / \mathrm{s} ; \\
& Q^{\text {mean }}=\text { mean of n values; } \\
& Q_{\text {mean }}^{\text {sim }}=\text { mean of simulated values; } \\
& Q_{\text {mean }}^{\text {obs }}=\text { mean of observed values; }
\end{aligned}
$$

$n=$ number of observations.

The NSE can range from $-\infty$ to +1 , with 1 being a perfect agreement between the model and real (observed) data. The simulation results were 
considered to be good if NSE $\geq 0.75$, and satisfactory if $0.36 \leq \mathrm{NSE} \leq 0.75$ [46]. The PBIAS (percent bias) measure the average tendency of the simulated data to be larger or smaller than their observed counterparts. A positive value indicates a model bias toward underestimation, whereas a negative value indicates a bias toward overestimation [47]. The PBIAS $< \pm 25 \%$ is satisfactory [48]. The PBIAS is calculated with Eq. (2).

$$
\text { PBIAS }=\left[\frac{\sum_{i=1}^{n}\left(Q_{i}^{o b s}-Q_{i}^{\text {sim }}\right) \times 100}{\sum_{i=1}^{n}\left(Q_{i}^{\text {obs }}\right)}\right]
$$

The coefficient of determination $R^{2}$ value is an indicator of the strength of the linear relationship between the observed and simulated values. It ranges from 0.0 to 1.0 , with higher values indicating better agreement. The $R^{2}$ is calculated with Eq. (3).

$$
R^{2}=\frac{\left[\sum_{i=1}^{n}\left(Q_{i}^{\text {sim }}-Q_{\text {mean }}^{\text {sim }}\right)\left(Q_{i}^{\text {obs }}-Q_{\text {mean }}^{\text {obs }}\right]^{2}\right.}{\sum_{i=1}^{n}\left(Q_{i}^{\text {sim }}-Q_{\text {mean }}^{\text {sim }}\right)^{2} \sum_{i=1}^{n}\left(Q_{i}^{\text {obs }}-Q_{\text {mean }}^{\text {obs }}\right)^{2}}
$$

\subsection{Catchment Management Intervention Scenarios}

Agricultural conservation practices, often called best management practices or BMPs, are widely used as effective measures for preventing or minimizing pollution from nonpoint sources within agricultural watersheds. SWAT already has an established method for modeling several agricultural practices including changes in fertilizer and pesticide application, tillage operations, crop rotation, dams, wetlands and ponds. The model also has the capacity to represent many other commonly used practices in agricultural fields through alteration of its input parameters [49]. Ten important agricultural conservation practices were selected for representation with the SWAT 2005 model and a number of previous modeling studies have used SWAT to evaluate conservation practices around the globe [50]. However, selection of BMPs and their parameter values are site specific and should reflect the study area reality [21]. For this study, we selected BMPs based on the previous traditional soil and water conservation practices on Ethiopian highlands. Currently, some of these practices are largely under implementation through community based participatory watershed development of Ref. [45], Ethiopia. The baseline values for the input parameters could be selected by: (1) a model calibration procedure; or (2) a "suggested" value obtained from the literature, previous studies in the study area, or prior experience of the analyst [50]. For this study, the baseline values which will represent the basin existing condition (Scenario 0) for the input parameters have been selected based on the suggested value obtained from the literature. For Scenarios 1 and Scenario 2, the BMPs were represented in SWAT model by modifying the SWAT parameters to reflect the effect the practice has on the processes simulated within SWAT [49]. The scenarios simulated and representation of BMPs in the SWAT are depicted in Table 1.

\begin{tabular}{|c|c|c|c|c|c|}
\hline \multirow{2}{*}{ Scenarios } & \multirow{2}{*}{ Description of BMP } & \multicolumn{4}{|c|}{ SWAT parameter used } \\
\hline & & Parameter name & Input file & PRE BMP/Calibration value & Post-BMP/Modified value \\
\hline Scenario 0 & Baseline & & & & \\
\hline Scenario 1 & Filter strip & FILTERW & 0 & 0 & $1 \mathrm{~m}$ \\
\hline \multirow{5}{*}{ Scenario 2} & \multirow{5}{*}{ Stone/soil bund } & SLSUB & $0-10 \%$ & $30 \mathrm{~m}$ & $17.5 \mathrm{~m}^{*}$ \\
\hline & & \multirow{2}{*}{ BSN } & $10-20 \%$ & $30 \mathrm{~m}$ & $11 \mathrm{~m}^{*}$ \\
\hline & & & $20-260 \%$ & $30 \mathrm{~m}$ & $10^{\mathrm{min}^{* * *}}$ \\
\hline & & $\mathrm{CN} 2$ & & $* *$ & $* *$ \\
\hline & & USLE_P & & 1.0 & 0.5 \\
\hline Scenario 3 & Reforestation & & & $* * * *$ & $* * * *$ \\
\hline
\end{tabular}

Table 1 Scenario description and SWAT parameters used to represent BMPs.

*The average values taken from Community Based Participatory Watershed Development Guideline; **The calibration value for discharge is maintained; min***minimum value of SLSUBBSN in SWAT model; ****assigned by SWAT model. 
In Scenario 1, filter strips were placed on all CRDY (dry land, cropland and pasture), all soil types and slope classes. The effect of filter strip is to reduce sediment, dissolved contaminants and sediment adsorbed organics in runoff [51]. Appropriate model parameter for representation of the effect of filter strips is FILTERW (width of filter strip). The filter width value, FILTERW, of $1 \mathrm{~m}$ was assigned to simulate the impact of filter strips on sediment trapping. The FILTERW value was assigned based on local research experiences in the Ethiopian highlands $[52,53]$. In Scenario 2, stone/soil bunds were placed on all CRDY (dry land cropland and pasture), all soil types and slope classes. This practice has a function to reduce overland flow, sheet erosion and reduce slope length [49]. This BMP was selected as it was the most widely and most intensively used soil conservation practice in the area [54]. Appropriate parameters for representing the effect of stone bunds are the $\mathrm{CN}$ (curve number), average slope length (SLSUBBSN) and the USLE_P support practice factor (USLE_P). The SWAT assigned value of the USLE_P value of 1.0 is used prior to the application of BMPs. The modified value/Post-BMP value for USLE_P of 0.5 was assigned based on Ref. [52] being the $\mathrm{P}$ factor recommended for all types of bunds in Ethiopia. The average slope length (SLSUBBSN) for slopes $0-10 \%$ and $10 \%-20 \%$ is taken from the community based participatory watershed development guideline which is currently under implementation in Ethiopian highlands. The minimum acceptable SLSUBBSN by SWAT is model $10 \mathrm{~m}$ and this value is assigned for slopes greater than $20 \%$. In Scenario 3, we simulated the impact of reforestation on sheet erosion. The reforestation has a function to reduce over land flow and rainfall erosivity. The reforestation effect was simulated by introducing land use change. Thus we replaced $1.0 \%$ of the area occupied by CRDY (dry land cropland and pasture) in to evergreen forest.

\section{Results and Discussion}

\subsection{Model Calibration and Validation}

The most sensitive parameters for flow predictions were CN2 (curve number), ALPHA_BF (baseflow alpha factor), GW_DELAY (groundwater delay time), GW_REVAP (ground water "re-vap" co-efficient), REVAPMN (threshold water depth in the shallow aquifer for "revap"), ESCO (soil evaporation compensation factor), SOL_AWC (available water capacity) and CANMX (maximum canopy storage). Table 2 shows the most sensitive parameters and fitted values. These flow parameters were adjusted within the given limits to initiate auto calibration. As measured data is not available on sediment yield, only the modeled data has been used to identify the impact of adjusting a parameter value on some measure of simulated sediment output. Accordingly, most sensitive parameters ranked 1 to 3 were USLE_P (USLE support practice factor), USLE_C (USLE land cover factor), and $\mathrm{Ch}$ K2, respectively. The parameters Ch-Cov (channel cover factor), Ch-erod (channel erodibility factor), exponent of re-entrainment parameter for channel sediment routing (spexp) and linear re-entrainment parameter for channel sediment routing (spcon) were equally important with rank 8. The SWAT flow predictions were calibrated against daily and monthly average flows with a warm up period of three years from 1983 to 1992 and validated from 1993 to 2002 at Asendabo gauging station, as shown in Figs. 2 and 3. The simulated daily flow matched the observed values for calibration period with NSE, PBIAS and $\mathrm{R}^{2}$ equal to $0.684,-13.9 \%$ and 0.726 , respectively. For the validation period, and the observed daily flows showed acceptable agreement as indicated by NSE, PBIAS and $R^{2}$ values equal to $0.640,-5.2 \%$ and 0.662 , respectively.

The simulated monthly average flow values also matched the observed values for calibration period with NSE and $R^{2}$ values equal to 0.54 and 0.886 , 
Daily discharge calibration at Asendabo gauging station

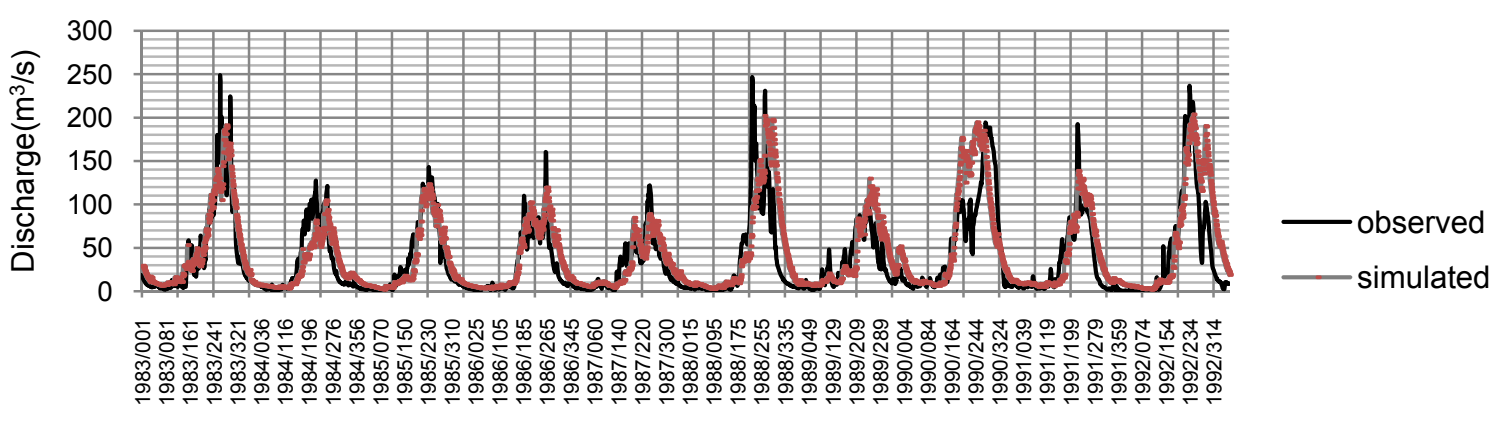

Year/day

(a)

Daily discharge validation at Asendabo gauging station

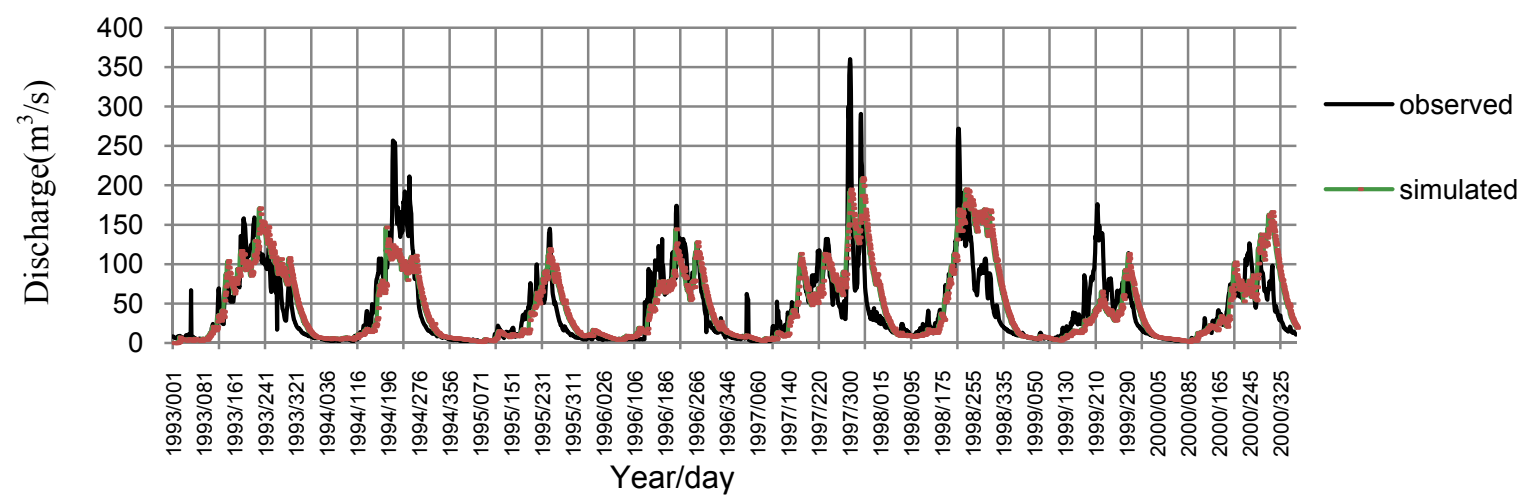

(b)

Fig. 2 Observed and simulated daily hydrographs at Asendabo Station: (a) calibration; (b) validation.

respectively. The calibration parameters were checked for the validation period and found to be 0.629 and 0.696 for NSE and $R^{2}$, respectively.

The model simulated well the discharge on the rising limb of the hydrograph. While, the falling limb of the hydrograph indicated that the simulated discharge is slightly greater than the observed discharge data for the whole calibration and validation period, and the crest segment of the hydrograph show the simulated peak discharge to be slightly less than the observed peak discharge. Generally, as it was shown by model performance evaluation criteria, the SWAT model performed well in simulating stream flow hydrograph for this study. Besides, the performance of SWAT model, Ndomba and Griensven [55] indicated that the SWAT model can satisfactorily estimate sediment yield for even poorly gauged catchments of East African countries.

\subsection{Scenario Analysis}

The assessment of the spatial variability of soil erosion is useful for catchment management planning [12]. The soil erosion prone areas in the Gilgel Gibe-1 basin are shown in Fig. 4 The SWAT model simulation shows erosion extent varies from negligible erosion to $39 \mathrm{t} / \mathrm{ha}$. Based on the classification of erosion rates in the Ethiopian highlands [56] the erosion level which are classified as high and very high in sub-basin 1, 3, 5 and 8 of Gilgel Gibe-1 basin corresponds to moderate erosion level (20-70 t/ha/yr). The erosion level in the sub basin 1, 3, 5 , and 8 is in the range of $20 \mathrm{t} / \mathrm{ha}$ to the maximum value of $39 \mathrm{t} / \mathrm{ha}$. The erosion level which are indicated as medium in sub-basins-2, 38 and 46 are relative to 


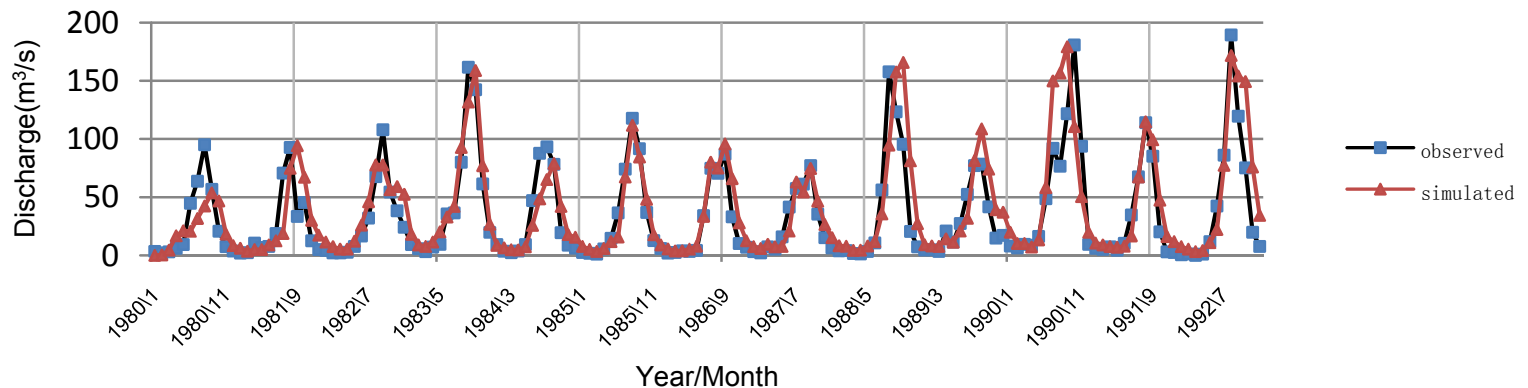

(a)

Monthly discharge Validation at Asendabo gauging station

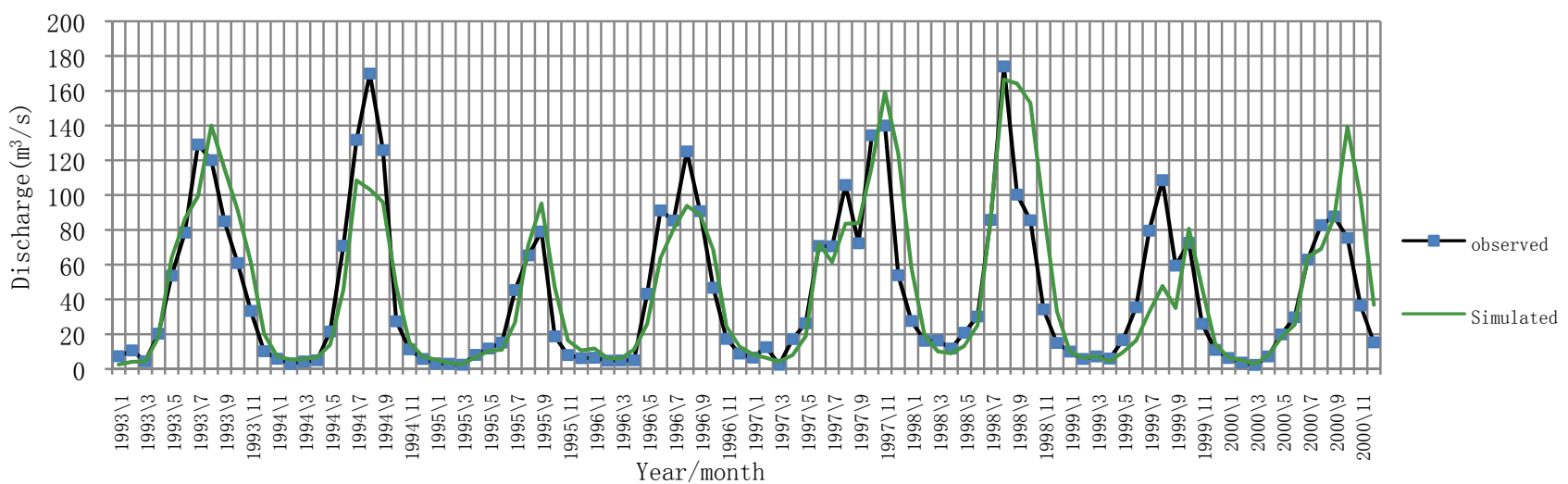

(b)

Fig. 3 Observed and simulated monthly hydrographs at Asendabo Station: (a) calibration; (b) validation.

Table 2 SWAT sensitive parameters and fitted values.

\begin{tabular}{lll}
\hline Parameter name & Description & Parameter value \\
\hline m-CN2.mgt* & Curve number & 0.8 \\
a-ALPHA_BF.gw** & Base flow alpha factor & 0.302 \\
r-GW_DELAY.gw & Groundwater delay time & 45 \\
r-GW_REVAP.gw & Groundwater revap co-efficient & 0.20 \\
r-REVAPMN.gw & Threshold water depth in the shallow aquifer for revap & 0.15 \\
r-ESCO.hru & Soil evaporation compensation factor & 0.25 \\
m-SOL_AWC.sol & Available water capacity & 1.67 \\
a-CANMX.hru & Maximum canopy storage & 4 \\
\hline
\end{tabular}

*The extension (e.g., .mgt) refers to the SWAT input file where the parameter occurs;

**The qualifier (a-) refers to the substitution of a parameter by adding the parameter values indicated in Table 2 and (m-) refers to the relative change in the parameter where the value from the SWAT database is multiplied by the values in the table. And (r-) refers to replacement in the parameter from the SWAT database by the values indicated in the table.

remaining sub-basins and their erosion level is in the range of $10 \mathrm{t} / \mathrm{ha}$ to $20 \mathrm{t} / \mathrm{ha}$. Generally, the SWAT simulation results for Gilgel Gibe-1 basin indicate that the sub-basins $1,2,3,5,8,38$ and 46 have the high rate of erosion relative to the remaining sub-basins.
The sub-basins with high rate of erosion have a maximum percentage of nearly $60 \%$ land-use of CRDY (dry land cropland and pasture) while the sub-basins with very low soil erosion rate have got $0-9 \%$ dry land, cropland and pasture as their landuse. 
These simulation results show the relative variations of soil erosion level within a sub-basin. These results are helpful to prioritize BMPs implementation area. Moreover, these results showed that the sediment yield to Gilgel Gibe-1 reservoir is mainly from sub-basins of the tributaries of Nedhi, and Bulbul which are to the left side of Gilgel Gibe River and at a close proximity to the reservoir.

The SWAT model simulation for the existing condition predicted the sediment yield at the outlet of Gilgel Gibe-1 basin, which is an inlet to Gilgel Gibe dam reservoir to be $122.73 \times 10^{3} \mathrm{t} / \mathrm{yr}$. However, running the model with different catchment management scenarios provided interesting results. The simulation of filter strips scenario reduced the total sediment yield to $79.82 \times 10^{3} \mathrm{t} / \mathrm{yr}$ from current condition at the same outlet location, which is equivalent to $35 \%$ reduction. The simulation of stone/soil bunds reduced the sediment yield to $23.26 \times$ $10^{3} \mathrm{t} / \mathrm{yr}$ from the current conditions, which is equivalent to $81 \%$ reduction. This result is comparable to the results reported in the literature. Herweg and Luid [53] reported $72 \%-100 \%$ sediment yield reductions by stone bunds at plot scale in Ethiopian and the Eritrean highlands. The simulation of reforestation scenario (Scenario 3) showed the average reduction of sediment yield by $9.1 \%$ for sub-basins 1 , $3,5,8,2,38$ and 46 from the current condition. This less sediment reduction under Scenario 3 as compared to Scenario 1 and 2 could be attributed to smaller implementation area. The average sediment reduction at sub-basin level where the sub-basin has got dry land CRDY greater than $10 \%$ of its total area under filter strip scenario was $35 \%$. This is comparable with results reported by Betrie et al. [21]. They reported the sediment reductions under filter strip scenario ranged from $29 \%$ to $68 \%$. In this study, the percentage sediment yield reduction per ha at sub-basin level increased with an increase in the percentage area of CRDY which was provided with filter strip width of 1 $\mathrm{m}$. The sub-basins such as sub-basins $15,16,23,48$ and 50 with percentage area of dry land, CRDY (cropland and pasture) less than $10 \%$ showed the sediment yield reduction efficiency of $0 \%$ under filter strip scenario. The effectiveness of BMPs per hectare for the sub-basins with different percentage of dry land, CRDY (cropland and pasture) is shown in Fig. 5.

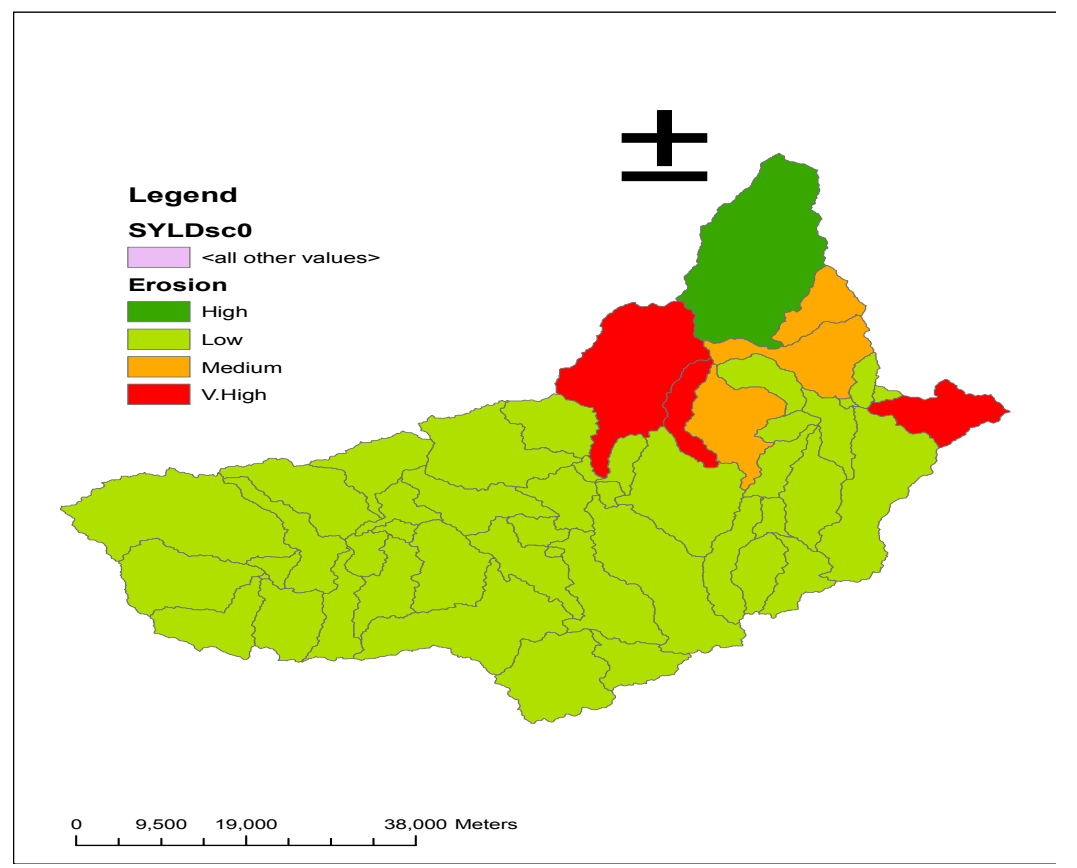

Fig. 4 Erosion prone areas in Gilgel Gibe basin. 

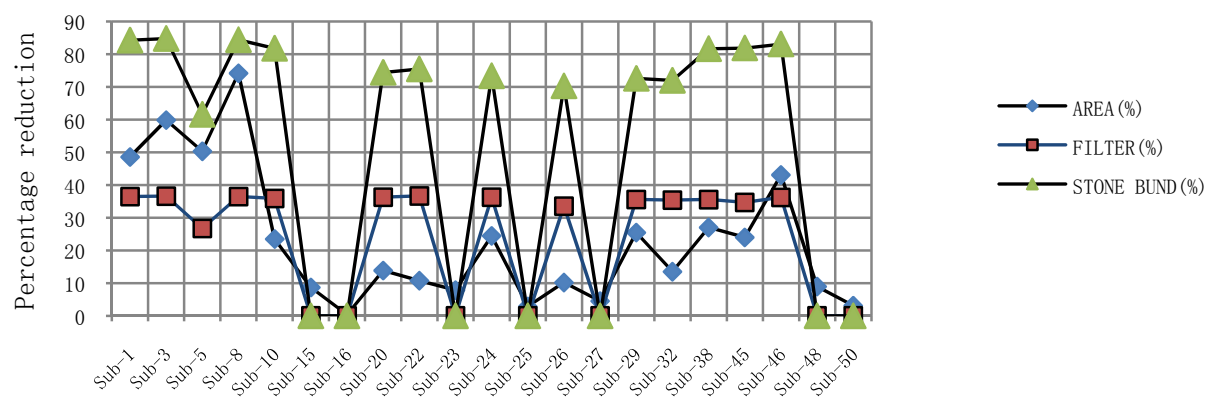

Fig. 5 Percentage of CRDY in the subbasin and sediment reduction efficiency of Scenarios 1 and 2.

\section{Conclusions}

The SWAT model was applied to assess the impact of the three BMPs (best management practices) scenarios on sediment reduction in the Gilgel Gibe river basin. The impact of further subdivision of the sub-basins in to more number of HRUs on the effectiveness of BMPs on sediment reduction was also checked. The model showed that the erosion prone areas at sub-basin level, which is useful information for catchment management planning and for the implementation of the watershed development program. The watershed development program through community based participatory approach under implementation throughout the country. This study result showed that the implementation of the three BMPs could reduce the soil erosion and sediment yield at the sub-basin and basin level. One of the three BMPs, namely soil/stone bunds has been practiced and implemented in some of the districts in the study watershed. The same practice is widely under implementation in Gilgel Gibe basin as per the decision made by the Ethiopian Government to promote and expand community watershed development in the country. However, the cost of implementing the BMPs should be evaluated. Additional BMPs should also be investigated and the best ones combined to form other scenarios which reduce soil erosion and sedimentation. This study shows as the modeling approach could be helpful for decision makers to prioritize the areas of intervention. In order to obtain a better estimate of the effectiveness of the filter strips, further investigation should be undertaken by using the improved VFS (vegetative filter strip) sub-model of SWAT 2009 version. Furthermore, SWAT 2009_LUC, a tool to activate the land use change module in SWAT 2009 should be applied for further investigations.

\section{References}

[1] R. Devi, T. Subalewu, L. Worku, L. Bishaw, B. Abebe, Assessment of siltation and nutrient enrichment of Gilgel Gibe dam, Southwest Ethiopia, Bio. Resource Technology 99 (2008) 975-979.

[2] E. Gizaw, W. Legesse, A. Haddis, B. Deboch, W. Birke, Assessment of factors contributing to eutrophication of Abasamuel water reservoir in Addis Ababa Ethiopia, Journal of Health Science 14 (2) (2004) 112-113.

[3] D.K. Borah, M. Bera, Watershed-scale hydrologic and nonpoint-source pollution models: Review of mathematical bases, T. ASAE 46 (2003) 1553-1566.

[4] W.S. Merrit, R.A. Letcher, A.J. Jakeman, A review of erosion and sediment transport models, Environ. Modell. softw. 18 (2003) 761-799.

[5] R.A. Young, C.A. Onstad, D.D. Bosch, W.P. Anderson, AGNPS: A non point sourse pollution model for evaluating agricultural watersheds, Journal of Soil and Water Conser-Vation 44 (2) (1989) 168-173.

[6] D.B. Beasley, L.F. Huggins, ANSWERS (Areal Nonpoint Source Watershed Environ-ment Response Simulation): User's Manual, U.S. Environmental Protection Agency, Chi-cago, Illions, 1982. 
[7] W.G. Knisel, CREAMS: A Field Scale Model for Chemicals, Runoff and Erosion from Agricultural Management Systems, USDA conservation research report, Washington, D.C., 1980.

[8] J.R. Williams, Chapter 25: The EPIC model, in: V.P. Singh (Ed.), Computer Models of Watershed Hydrology, Water Resources Publications, Highlands Ranch, 1995, pp. 909-1000.

[9] J. Schmidt, M.V. Werner, A. Michael, Application of the EROSION 3D model to the CATSOP watershed, The Netherlands, in: A. de Roo (Ed.), Modelling Soil Erosion by Water at the Catchment Scale, Catena, 1999, pp. 449-456.

[10] R.P.C. Morgan, J.N. Quinton, R.E. Smith, G. Govers, J.W.A. Poesen, K. Auerswald, et al., The European soil erosion model (EUROSEM): A dynamic approach for predicting sediment transport from fields and small catchments, Earth Surface Processes and Landforms 23 (6) (1998) 527-544.

[11] J.G. Arnold, R. Srinivasan, R.S. Muttiah, J.R. Williams, Large area hydrologic modelling and assessment Part I: Model development, J. Am. Water Resour. As. 34 (1998) 73-89.

[12] J.M. Laflen, J.L. Lane, G.R. Foster, WEPP (The water erosion prediction project)—A new generation of erosion prediction technology, J. Soil and Water Conserve 46 (1) (1991) 34-38.

[13] G. Zeleke, Landscape Dynamics and Soil Erosion Process Modelling in the North-Western Ethiopian Highlands, in: African Studies Series A, Geographica Bernensia, Berne, 2000.

[14] N. Haregeweyn, F. Yohannes, Testing and evaluation of the agricultural non-point source pollution model (AGNPS) on Augucho catchment, western Hararghe, Ethiopia, Agr. Ecosyst. Environ. 99 (2003) 201-212.

[15] H. Mohammed, F. Yohannes, G. Zeleke, Validation of agricultural non-point source (AGNPS) pollution model in Kori watershed, South Wollo, Ethiopia, Int. J. Appl. Earth. Obs. 6 (2004) 97-109.

[16] H. Hengsdijk, G. Meijerink, M. Mosugu, Modeling the effect of three soil and water conservation practices in Tigray, Ethiopia, Agr. ecosyst. Environ. 105 (2005) 29-40.

[17] T. Steenhuis, A. Collick, Z. Easton, E. Leggesse, H. Bayabil, E. White, et al., Predicting discharge and sediment for the Abay (Blue Nile) with a simple model, Hydrol. Process. 23 (2009) 3728-3737.

[18] S. Setegn, B. Dargahi, R. Srinivasan, A. Melesse, Modeling of sediment yield from Anjeni-Gauged watershed, Ethiopia using SWAT model, Journal of American Water Resources As. 46 (2010) 514-526.

[19] G.B. Tesfahunegn, P.L.G. Vlek, L. Tamene, Management
Strategies for reducing soil degradation through modeling in a GIS environment in northern Ethiopia catchment, Nutrient Cycling in Agroecosystems 92 (2012) 255-272.

[20] M.T. Asres, S.B. Awulachew, SWAT based runoff and sediment yield modeling, a case study of the Gumera watershed in the Blue Nile Basin, Ecohydrology and Hydrobiology 10 (2010) 191-200.

[21] G.D. Betrie, Y.A. Mohamed, A. van Griensven, R. Srinivasan, Sediment management modeling in the Blue Nile Basin using SWAT model, Hydrol. Earth Syst. Sci. 15 (2011) 807-818.

[22] Community Based Participatory Watershed Development, Part 1: A Guideline, MOARD (Ministry of Agriculture and Rural Development), Addis Ababa, Ethiopia, 2005.

[23] S.L. Neitsch, J.G. Arnold, J. Kiniry, J.R. Williams, Soil and Water Assessment Tool Theoretical Documentation (Version 2005), USDA Agricultural Research Services and Texas A \& M Blackland Research Center, Temple, Texas, 2005.

[24] National Engineering Handbook, Section IV, Hydrology, USDA-SCS (US Department of Agriculture-Soil Conservation Service, 1972.

[25] W.H. Green, C.A. Ampt, Studies on soil physics: I. Flow of air and water through soils, J. Agr. Sci. 4 (1911) 1-24.

[26] J.R. Williams, Flood routing with variable travel time or variable storage coefficients, T. ASAE 12 (1969) 100-103.

[27] V.T. Chow, Open Channel Hydraulics, McGraw-Hill Book Company, New York, 1959.

[28] C. Priestley, R. Taylor, On the assessment of surface heat flux and evaporation using large-scale parameters, Mon. Weather Rev. 100 (1972) 81-92.

[29] J.L. Monteith, Evaporation and environment, Symp. Soc. Exp. Biol. 19 (1965) 205-234.

[30] G. Hargreaves, G. Hargreaves, J. Riley, Agricultural benefits for Senegal river basin, J. Irrig. Drain. E-ASCE 111 (1985) 113-124.

[31] J. Williams, H. Berndt, Sediment yield prediction based on watershed hydrology, T. ASAE 20 (1977) 1100-1104.

[32] J.G. Arnold, J.R. Williams, D.R. Maidment, Continuous time water and sediment-routing model for large basins, J. Hydraul. Eng-ASCE 121 (1995) 171-183.

[33] J. Williams, SPNM: A model for predicting sediment, Phosphorus, and nitrogen yields from agricultural basins, J. Am. Water. Resour. As. 16 (1980) 843-848.

[34] C. George, L.F. Leon, Water base: SWAT in an open source GIS, The Open Hydrology Journal 2 (2008) 1-6.

[35] A. Jarvis, H.I. Reuter, A. Nelson, E. Guevara, Hole-filled Seamless SRTM Data Version 4, International Centre for Tropical Agriculuture (CIAT), 2008, http://srtm.csi.cgiar.org (accessed Mar. 25, 2012).

[36] M. Hansen, R. DeFries, J. Townshend, R. Sohlberg, 1 km 
Land Cover Classification Derived from AVHRR, 1998, http://glcf.umiacs.umd.edu/data/landcover (accessed Apr. 1, 2012).

[37] Digital Soil Map of the World and Derived Soil Properties. Rev. 1. [CD ROM], FAO/UNESCO, 2003, http://www.fao.org/catalog/what_new-e.htm (accessed Apr. 1, 2012).

[38] L.F. Leon, Step by Step Geo-Processing and Set-up of the Required Watershed Data for MWSWAT (Map Window SWAT), Version 2, 2011.

[39] L.F. Leon, Map Window Interface for SWAT (MWSWAT), Version 1.8, 2010.

[40] CGIAR-CSI SRTM $90 \mathrm{~m}$ DEM Digital Elevation Database Website, http://srtm.csi.cgiar.org (accessed Apr. 6, 2012).

[41] GLCC (Global Land Cover Characterization) http://edesns17.cr.usgs.gov/glcc/glcc.html (accessed Apr. 1, 2012).

[42] Digital Soil Map of the World and Derived Soil Properties Food and Agricultural Organization of the United Nations, FAO (Food and Agricultural Organization), Rome, 1995.

[43] C.A. Reynolds, T.J. Jackson, W.J. Rawls, Estimated Available Water Content from the FAO Soil Map of the World, Global Soil Profile Databases, and Pedo-transfer Functions, 1999, http://www.ngdc.noaa.gov/seg /cdroms/ reynolds/reynolds/reynolds.htm (accessed Apr. 6, 2012).

[44] Waterbase Website, http://www.waterbase.org/ download (accessed Apr. 4, 2012)

[45] J.E. Nash, J.V. Sutcliffe, River flow forecasting through conceptual models Part I: A discussion of principles, Journal of Hydrolo. 10 (1970) 282-290.

[46] M.W. van Liew, J. Garbrecht, Hydrologic simulation of the little Washita river experimental watershed using SWAT, J. Am. Water Resour. Assoc. 39 (2) (2003) 413-426.

[47] H. Gupta, S. Sorooshian, P. Yapo, Status of automatic calibration for hydrologic models: Comparison with multilevel expert calibration, J. Hydrol. Eng. 4 (1999) 135-143.

[48] M.W. van Liew, T.L. Veith, D.D. Bosch, J.G. Arnold, Suitability of SWAT for the conservation effects assessment project: Comparison on USDA agricultural research service watersheds, J. Hydrol. Eng. 12 (2) (2007) 173-189.

[49] K. Bracmort, M. Arabi, J. Frankenberger, B. Engel, J. Arnold, Modeling long-term water quality impact of structural BMPs, T. ASABE 49 (2006) 367-374.

[50] M. Arabi, J.R. Frankenberger, B.A. Engel, J.G. Arnold, Representation of agricultural conservation practices with SWAT, Hydrological Processes 22 (16) (2008) 3042-3055.

[51] P. Tuppad, N.K.R. Srinivasan, C.G. Rossi, J.G. Arnold, Simulation of agricultural management alternatives for watershed protection, Water Resour. Manage 24 (12) (2010) 3115-3144.

[52] H. Hurni, Erosion-productivity-conservation systems in Ethiopia, in: Proceedings of the 4th International Conference on Soil Conservation, Maracay, Venezula, 1985, pp. 654-674.

[53] K. Herweg, E. Ludi, The performance of selected soil and water conservation measures-Case studies from Ethiopia and Eritrea, Catena 36 (1999) 99-114.

[54] Y. Anley, A. Bogale, A. Haile-gabriel, Adoption decision and use intensity of soil and water conservation measures by small holder subsistence farmers in Dedo district, western Ethiopia, Land Degrad. Develop. 18 (2006) 289-302.

[55] P.M. Ndomba, A. van Griensven, Suitability of SWAT model for sediment yields modeling in the eastern Africa, advances in data, methods, models and their applications in geoscience, Technical Paper, University of Dares Salam, Dares Salaam, Tanzania, 2011.

[56] H. Hurni, Soil erosion and soil formation in agricultural ecosystems: Ethiopia and Northern Thailand, Mt. Res. Dev. 3 (1983) 131-142. 